\title{
SUBSTRATES AND INDOLE-3-BUTYRIC ACID IN MINI-CUTTINGS ROOTING OF Carya illinoinensis (WANGENH) K. KOCH
}

\author{
Márcio Alberto Hilgert ${ }^{1}$, Marília Lazarotto ${ }^{2 *}$, Larissa Campos de Sá3 ${ }^{3}$ Claudimar Sidnei Fior ${ }^{4}$, Paulo Vitor Dutra \\ de Souza ${ }^{4}$ \\ ${ }^{1 *}$ Doutorando do Programa de Pós-Graduação em Fitotecnia, Universidade Federal do Rio Grande do Sul, Porto Alegre, RS, \\ Brasil, marcioahilgert@yahoo.com.br \\ ${ }^{2}$ Professor Adjunto, Centro de Engenharias, Universidade Federal de Pelotas, Pelotas, RS, Brasil, marilia.lazarotto@ufpel.edu.br \\ ${ }^{3}$ Engenheira Agrônoma, Universidade Federal do Rio Grande do Sul, Porto Alegre, RS, Brasil, desa_larissa@hotmail.com \\ ${ }^{4}$ Professor, Departamento de Horticultura e Silvicultura, Universidade Federal do Rio Grande do Sul, Porto Alegre, RS, Brasil, \\ csfior@ufrgs.br,pvdsouza@ufrgs.br
}

Received for publication: 26/03/2020 - Accepted for publications: 19/03/2021

\section{Resumo}

Substratos e ácido indolbutírico no enraizamento de estacas juvenis de Carya illinoinensis (Wangenh) $C$. $K O C H$. A miniestaquia consiste em um método eficaz de manter as características desejáveis de plantas matrizes, bem como a uniformidade. O objetivo do presente trabalho foi determinar o substrato e concentrações de ácido indolbutírico (AIB) mais adequados para o enraizamento de miniestacas de Carya illinoinensis. O experimento foi realizado em estufa agrícola com nebulização intermitente, durante o período de fevereiro a maio de 2018. O delineamento experimental utilizado foi em blocos, com arranjo fatorial 3 x 5 (três substratos: casca de arroz carbonizada, vermiculita e perlita; e cinco concentrações de AIB: 0, 2.000, 4.000, 6.000 e 8.000 $\mathrm{mg} \mathrm{L}^{-1}$ ). As miniestacas utilizadas foram apicais, oriundas de mudas de oito meses de idade, produzidas por sementes, confeccionadas com 8 a $10 \mathrm{~cm}$ de comprimento e dois folíolos cortados ao meio. O uso de AIB influenciou nos resultados obtidos em conjunto com todos os substratos, exceto para variável número de raízes, no qual houve efeito apenas do AIB. Resultados superiores foram obtidos com o uso de AIB em conjunto com o substrato casca de arroz carbonizada, com obtenção do ponto máximo estimado de $91 \%$ de miniestacas enraizadas com a concentração de $3.957 \mathrm{mg} \mathrm{L}^{-1}$ de AIB. As demais variáveis avaliadas, exceto número médio de raízes, também obtiveram resultados superiores próximo a concentração $4.000 \mathrm{mg} \mathrm{L}^{-1}$ de AIB e uso de substrato casca de arroz carbonizada. Os resultados obtidos indicam a possibilidade de propagação de Carya illinoinensis pela técnica da miniestaquia e sendo está uma alternativa para produção de mudas clonais da espécie.

Palavras-chave: mudas clonais; nogueira-pecã; propagação assexuada; uniformidade.

\begin{abstract}
Mini-cutting technique of tree species is an effective method of maintaining desirable features of plant matrices and uniformity. The objective of the present research was to determine substrate and concentration of indolebutyric acid (IBA) more suitable for mini-cuttings of Carya illinoinensis rooting. The experiment was carried out in a greenhouse with mist, from February to May 2018. The used experimental design was in blocks with a factorial arrangement of $3 \times 5$, in which three substrates were tested: carbonized rice husk, vermiculite and perlit; and five IBA concentration : 0,2,000, 4,000, 6,000 and 8,000 mg L-1. The mini-cuttings were apical, produced from seedlings, with eight months of age. Mini-cuttings were made with two leaves cut in half and 8 to $10 \mathrm{~cm}$ in length. The use of IBA influenced results obtained with all substrates, except for the variable number of roots, in which only IBA effect was observed. However, higher results were obtained with IBA uses together with substrate carbonized rice husk, obtaining estimated maximum point of $91 \%$ of rooted minicuttings with 3,957 mg L-1 IBA concentration. For other evaluated variables, except root numbers, it was also observed superior results close to 4,000 mg L-1 IBA concentration with substrate carbonized rice husk. Results indicate the possibility of Carya illinoinensis propagation by mini-cutting technique and as an alternative for this specie plantlets production.
\end{abstract}

Keywords: plantlets; pecan; asexual propagation; uniformity.

\section{INTRODUCTION}

Carya illinoinensis (Wangenh.) K. Koch, popularly known in Brazil as nogueira-pecã (pecan nut) or, internationally as pecan, is a species belonging to Juglandaceae family, native to North America, in Mexico and United States territories. Its cultivation occurs mainly for nuts production, with world production in the 2017/2018 crop season of 124,000 tons of pecan nuts, in which United States and Mexico appear on the world stage as the largest producers and responsible for $92 \%$ of pecan nuts production (INTERNATIONAL NUT AND DRIED FRUIT COUNCIL FOUNDATION, 2018). In Brazil, there is an increase in cultivation area of $C$. illinoinensis, mainly in Rio Grande do Sul (RS) state, with more than 5,000 hectares cultivated (HAMANN et al., 2018), which, together with others producing states, makes Brazil the fourth largest world producer. 
For this species seedlings production, rootstocks are produced from open pollinated seeds of grafted cultivars (SANDERLIN, 2015), in other words, there is a great variability among them, causing diversity in orchard. The production time of seedlings of the species is a limiting factor, since seed rootstocks waits an average of one year to be grafted. Normally, one-year seedlings are used as rootstocks and this can extend the time to commercialize by up to two years.

In this context, its necessary to investigate other ways of propagation that can promote an increase seedlings production for this species, maintenance of important characteristics, such as productivity and uniformity of matrice plants, which could assist in orchards management. In several forest species cultivated for commercial purposes, vegetative propagation by cuttings and/or mini-cuttings was the solution for maintaining these favorable genetic conditions of selected plants, which may present advantages in abiotic and biotic stress conditions. An example of this type of problem is that there is no information available on the susceptibility of rootstocks used in nurseries for infection by Xyllela fastidiosa (SANDERLIN, 2015), a disease that has affected commercial orchards in the United States in recent years.

Cutting and/or mini-cutting is a vegetative propagation method that consists of detaching an organ, branch, leaf or root from a matrice plant and placing them in an appropriate medium or substrate for rooting and aerial part development (FACHINELLO et al., 2011). The main advantages of this propagation technique include maintenance of desirable characteristics among propagated plants and the possibility of total control of all phases of multiplication process.

Several factors are involved in rooting process of cuttings and/or mini-cuttings, such as matrice plants nutritional status, type of cuttings, temperature, hormonal balance and substrate (FACHINELLO et al., 2005). In order for adventitious roots to form, there is a need for presence of ideal hormone levels in plants that favor the process of rhizogenesis (XAVIER et al., 2013). According to Hartmann et al. (2011), among these hormones, auxins have a direct effect on roots formation in vegetative propagation, as they favor cellular activity and also act in signaling molecules in the development of events for root formation. They are considered the most important substances that promote adventitious rooting, mainly for species that have difficulty in rooting (PEREIRA et al., 2017), with the indole-3-butyric acid (IBA) being the most used auxin to stimulate the rooting of propagules, due to its low toxicity for most species (TRONCO et al., 2015).

Another important factor in mini-cutting propagation process is the choice and use of suitable substrates for this seedling production process. Physical and chemical substrates and mixtures properties can influence rhizogenesis process (HARTMANN et al., 2011). According to Kämpf et al. (2006), the substrate choice used in propagation must directly affect the quality of formed roots and rooting percentage. When choosing substrate, it is essential to select materials that allow sufficient water retention, so that there is no dehydration of the base of the piles and the presence of aeration spaces to facilitate gas exchange to favor the development of the radical system (YAMAMOTO et al., 2013).

A working hypothesis is that there is a combination of substrate and auxin applied exogenously which promote greater rooting and development of pecan seedlings. The aim of this study was to test combinations between substrates and concentrations of indole-3-butyric acid (IBA), which are more suitable for rooting Carya illinoinensis mini-cuttings.

\section{MATERIAL AND METHODS}

\section{Experiment location}

The experiment was conducted in an agricultural greenhouse with intermittent misting from Department of Horticulture and Silviculture of School of Agronomy of Federal University of Rio Grande do Sul, from February to May of 2018.

\section{Matrices production by seeds}

Mini-cuttings used in this experiment were obtained from 50 seedlings from seeds produced in a sector of Department of Horticulture and Silviculture of School of Agronomy. Seeds for these seedlings production were collected from six 38-year-old matrice plants, in an orchard of Carya illinoinensis, located at Agronomic Experimental Station of the School of Agronomy, in the municipality of Eldorado do Sul (latitude $30^{\circ} 07^{\prime} 08^{~ " S}$, longitude 51 39 '59" $\mathrm{W}$ and average altitude of $46 \mathrm{~m}$ ). Collection was carried out before natural fall of nuts, during April, 2017 month.

After seed collection, seeds were homogenized in a single batch and, subsequently, dried to $8 \%$ moisture. The water content was determined from percentage difference of the initial and final mass of four samples of 100 grams of seeds, after drying in an electric oven under a temperature of $105 \pm 3{ }^{\circ} \mathrm{C}$, during a 24-hour period (BRASIL, 2009). After drying, the seeds were stored in a cold chamber at a temperature of $5^{\circ} \mathrm{C}$ for 90 days until sowing was carried out. 
In July 2017, sowing was done in plastic packages with a volume of 2.8 liters $(12 \times 25 \mathrm{~cm})$, filled with commercial substrate Carolina Soil II ${ }^{\circledR}$, with composition according to the manufacturer of: Sphagnum peat, expanded vermiculite and carbonized rice hull. Two seeds were sown in each package, previously scarified at the top end of the seed with the aid of number 6 sandpaper. After the 60-day sowing period, seedling thinning was carried out, with only one seedling per package.

After 90 days of sowing, the fertilization of seedlings began. Fertilization took place at intervals of 14 days and application of $50 \mathrm{ml}$ plant $^{-1}$ of the solution formed by $10 \mathrm{~g} \mathrm{~L}^{-1}$ of the commercial fertilizer Kristalon ${ }^{\circledR}$. According to commercial information, the fertilizer used has the composition of $6 \%$ Nitrogen, $(4.5 \%$ in the nitric form and 1.5\% ammoniacal form), 12\% Phosphorus (P2O5), 36\% Potassium (K2O), $1.8 \%$ Magnesium (Mg), 8\% Sulfur (S), 0.07\% Iron (Fe), 0.025\% Boron (B), 0.01\% Copper (Cu), 0.04\% Manganese (Mn), 0.004\% Molybdenum (Mo) and $0.025 \%$ Zinc (Zn). In combination with the fertilization of the Kristalon® solution, $50 \mathrm{ml}$ plant $^{-1}$ of the solution of $1 \mathrm{~g} \mathrm{~L}^{-1}$ of calcium nitrate was applied, according to the commercial information of the product used, the concentration of $15.5 \%$ nitrogen (14.4\% in the nitric form and $1.1 \%$ in the ammoniacal form) and $26.5 \%$ of Calcium Oxide $(\mathrm{CaO})$. The seedlings were maintained throughout the experiment in a covered environment protected by side walls with $50 \%$ shade screens and with daily irrigation performed manually, according to climatic conditions and specific needs.

\section{Mini-cuttings collection}

180 days after the sowing was conducted to form the pecan nut matrice plants, topping was carried out to stimulate sprouting. After 21 days of the first topping, the second topping was performed to promote the increase of sprouting. The first collection to form the first two blocks of the experiment was carried out 21 days after the second topping; and the second collection of mini-cuttings to form the final two blocks was conducted 21 days after the first collection, using apical mini-cuttings. In each collection there was homogenization in a single batch of mini-cuttings, made with two leaflets cut in half, to reduce transpiration and, consequently, loss of water. The average length of each mini-cutting was 8 to $10 \mathrm{~cm}$, with a straight cut at the basal end of each mini-cutting.

\section{Experimental treatments and conditions}

The average temperature and relative humidity of the agricultural greenhouse air with intermittent misting were monitored daily using the AKSO® digital thermo-hygrometer (Figure 1).
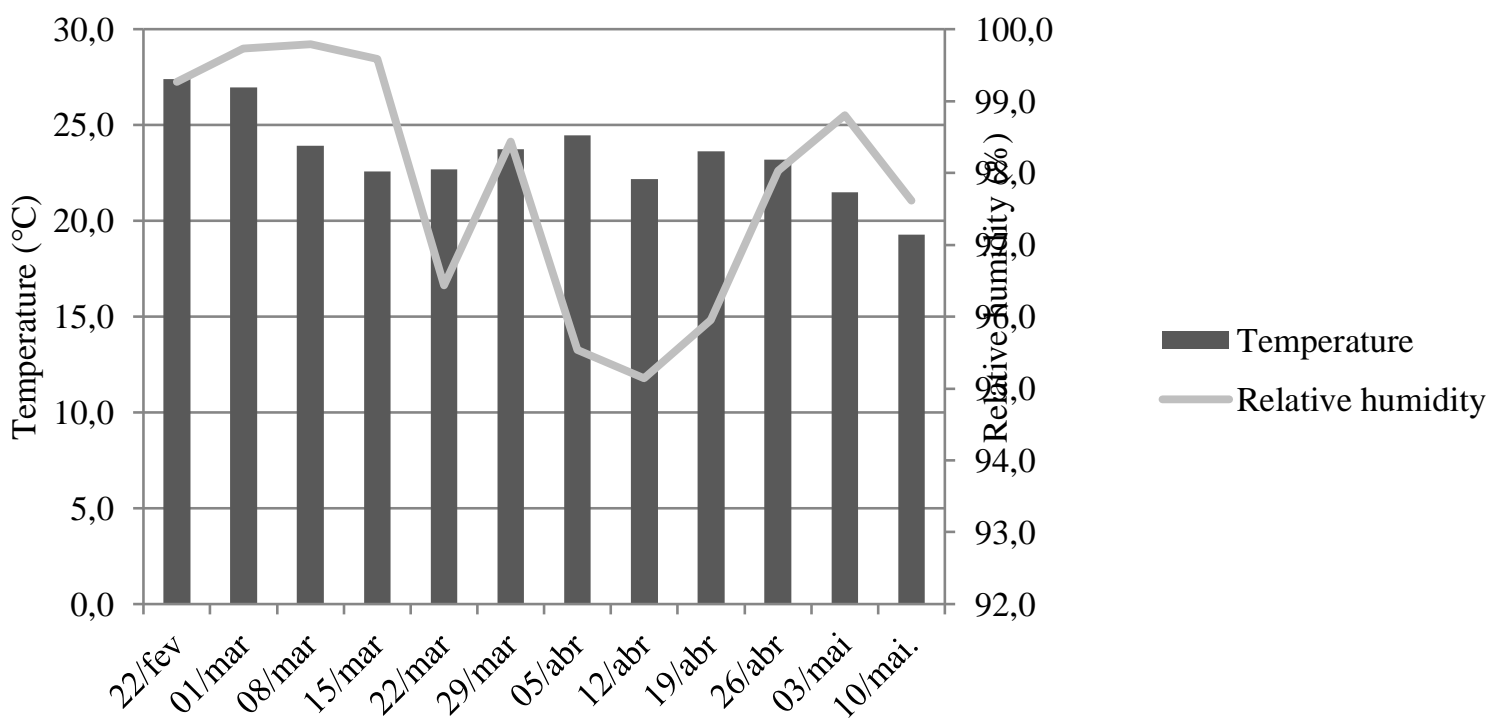

Figure 1. Weekly averages of temperature and relative humidity of the air inside the agricultural greenhouse with intermittent misting from February 22 to May 14, 2018.

Figura 1. Médias semanais de temperatura e umidade relativa do ar no interior da estufa agrícola com nebulização intermitente no período de 22 de fevereiro a 14 de maio de 2018.

The trial design used was in blocks, using a 3 x 5 factorial scheme (substrates x concentrations of indole3-butyric acid - IBA), with four blocks of 10 mini-cuttings/plot and with a total of 40 mini-cuttings per treatment. The treatments consisted of a combination of three substrates: carbonized rice hulls, vermiculite and perlite; and five concentrations of IBA: 0. 2.000, 4,000, 6,000 and 8,000 $\mathrm{mg} \mathrm{L}^{-1}$. 
The IBA treatments came from hydroalcoholic solutions, to improve the dissolution of IBA, using indole3-butyric acid (C12 H13 NO2) P.A. (practical grade) and with 99\% purity (Vetec $囚)$, using 50\% as solvent of ethyl alcohol (48\%) and the remainder of the solution made up with distilled water (1:1), adapted from Fachinello et al. (2005). In order to improve penetration, the bases of the collected mini-cuttings were immersed for a period of 10 seconds in the hydroalcoholic solutions of IBA (ZEM et al., 2016). Subsequently, the mini-cuttings were packed in expanded polyethylene trays with 50 cells $(58 \times 30 \times 9 \mathrm{~cm})$ and a volume of $100 \mathrm{~cm}^{3} / \mathrm{cell}$, filled with the respective substrate treatments. The mini-cuttings were maintained on masonry benches in an agricultural greenhouse with intermittent nebulization, using nebulizers with a flow capacity of $6 \mathrm{~L} \mathrm{hour}^{-1}$. The irrigation period consisted of 15 seconds and triggered every 5 minutes during the day ( 7 am to $7 \mathrm{pm}$ ) and irrigation of 15 seconds and triggered every 15 minutes during the night ( $7 \mathrm{pm}$ to $7 \mathrm{am})$.

The substrates used in the treatments of the experiment were submitted to chemical and physical analysis, to evaluate important variables that can influence the propagation process of Carya illinoinensis mini-cuttings, such as $\mathrm{pH}$, electrical conductivity, aeration space and water retention capacity under suction of $10 \mathrm{~cm}$. The complete chemical and physical analysis was performed with samples taken at the time of installation and after the period of evaluation of the experiment had passed.

\section{Experiment evaluations}

The evaluations were conducted 60 days after the installation of the treatments of the experiment. The evaluated and calculated variables included mini-cuttings with callus formation (\%), rooting (\%), live minicuttings $(\%)$, sprouting $(\%)$, leaf retention $(\%)$, average number of roots per mini-cuttings, average length of the three largest roots of mini-cuttings $(\mathrm{cm})$, average fresh and dry root mass $(\mathrm{mg})$. The average length of the three largest roots of mini-cuttings was obtained with the use of a graduated ruler. The fresh and dry root mass was weighed on a precision analytical scale, and the dry mass obtained after stabilizing the weight in a drying oven at $65^{\circ} \mathrm{C}$, which occurred after a 72 hour period. The roots used for determining the fresh weight were previously subjected to cleaning in running water to remove the remains of substrate and after being weighed were placed in the drying oven.

The data obtained was subjected to analysis of variance (ANOVA) and polynomial regression for significant results between the interaction of factors and IBA concentrations, with the adoption of the model that showed a significant difference by the F test $(\mathrm{p}<0.05)$. Pearson's correlation was also performed between the callus formation and rooting variables. The statistical analysis was performed using the programs Sigmaplot, version 10.0 and Sisvar, version 5.6.

\section{RESULTS}

Regarding the results, there was significant interaction between the different substrates and IBA concentrations for the mini-cuttings with callus formation, rooting, average length of the three largest roots, average dry and fresh mass of mini-cutting roots. For the variable average number of roots per mini-cutting, only the IBA concentration was significant. The variables of live mini-cuttings, leaf retention and sprouting were not significant, with the following averages of $94.5 \%, 92 \%$ and $77.5 \%$, respectively.

Through the polynomial regression analysis, the mentioned variables that showed significance for interaction, showed negative quadratic behavior, except for the average length variable of the three largest roots, in which the interaction between the vermiculite substrate and IBA concentrations showed linear behavior.

Callus formation and rooting variables obtained superior results up to their respective estimated maximum points of IBA concentrations, with $94 \%$ of mini-cuttings with callus formation with the concentration of $4.032 \mathrm{mg}$ $\mathrm{L}^{-1}$ of IBA (Figure $2 \mathrm{~A}$ ) and $91 \%$ of mini-cuttings rooted with the concentration of $3.957 \mathrm{mg} \mathrm{L}^{-1}$ of IBA (Figure 2B), both concentrations in combination with the substrate of carbonized rice hull. The callus formation and rooting variables showed similar results, in which it was observed that there was only rooting in mini-cuttings with the presence of callus.

From the point of maximum efficiency, close to $4,000 \mathrm{mg} \mathrm{L}^{-1}$, both variables decreased (Figures $2 \mathrm{~A}$ and $\mathrm{B})$, in addition to necrosis of the base of the mini-cuttings, in which the most concentrated IBA solutions were applied (Figure 3A). 

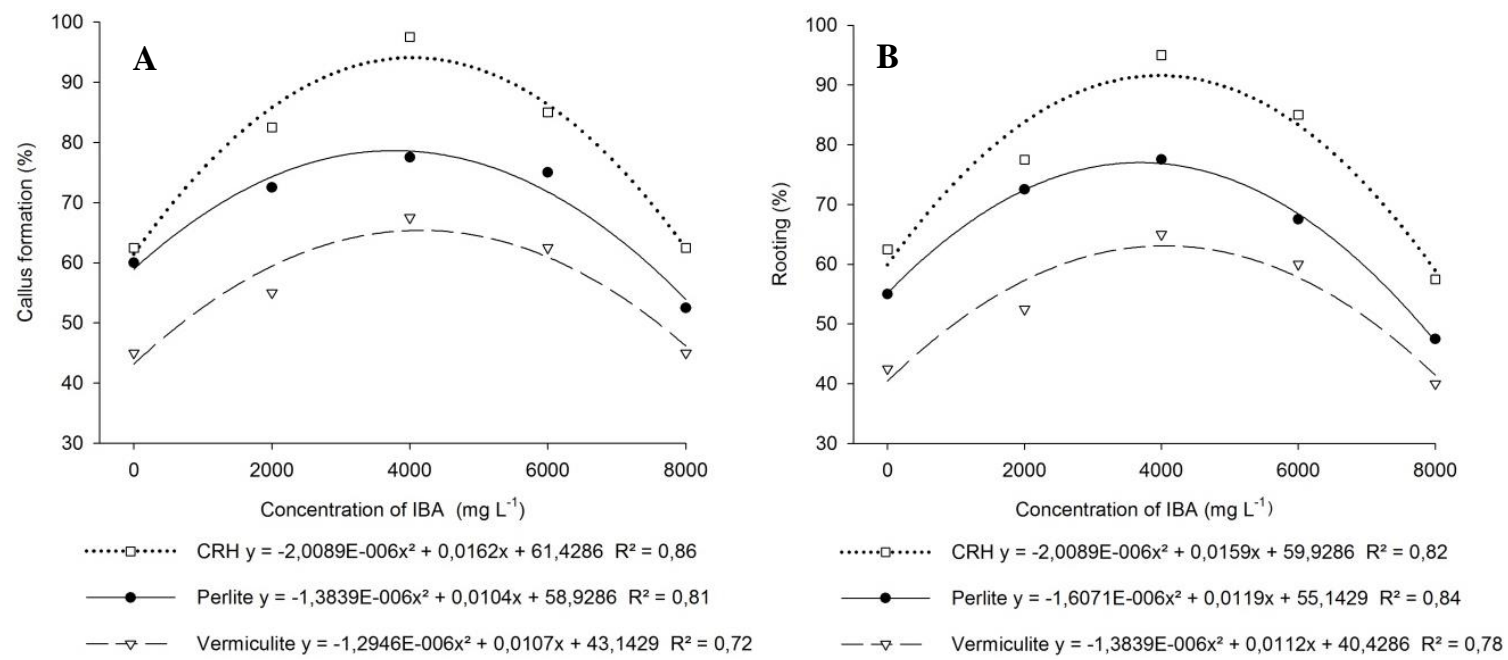

Figure 2. Callus formation (A) and rooting (B) of mini-cuttings of Carya illinoinensis submitted to different concentrations of IBA and substrates. CRH: Carbinized Rice Hull.

Figura 2. Formação de calos (A) e enraizamento (B) de miniestacas de Carya illinoinensis submetidas a diferentes concentrações de AIB e substratos. CAC: Casca de Arroz Carbonizada.

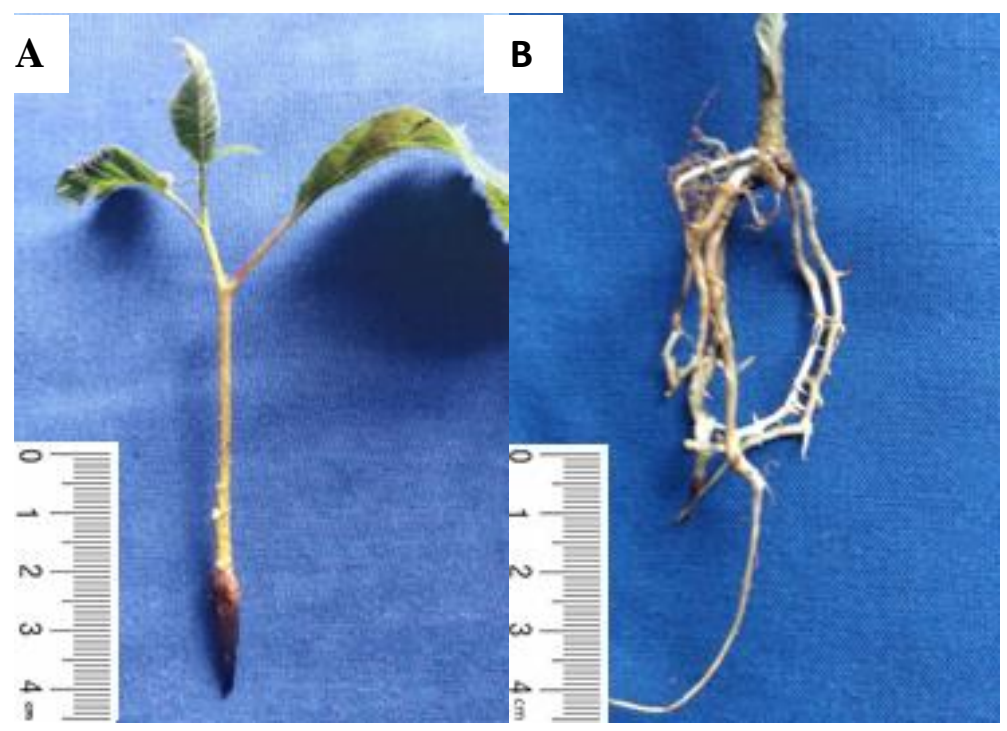

Figure 3. Basal necrosis using the concentration of $8,000 \mathrm{mg} \mathrm{L}^{-1} \mathrm{IBA}(\mathrm{A})$ and rooting using the concentration of $4,000 \mathrm{mg} \mathrm{L}^{-1}(\mathrm{~B})$ of Carya illinoinensis mini-cuttings in carbonized rice hull substrate.

Figura 3. Necrose na extremidade basal com o uso da concentração de $8.000 \mathrm{mg} \mathrm{L}^{-1}$ AIB (A) e enraizamento com o uso da concentração de $4.000 \mathrm{mg} \mathrm{L}^{-1}$ (B) de miniestacas de Carya illinoinensis em substrato casca de arroz carbonizada.

There was no significant interaction between concentrations and substrate for variable number of roots, but there was a significant effect of IBA concentrations with negative quadratic behavior of the regression curve (Figure 4A). The highest number of roots was obtained with the maximum point estimated with the concentration of $4,922 \mathrm{mg} \mathrm{L}^{-1}$ of IBA, with an average of 3.74 roots/ mini-cutting, highlighting the positive effect of IBA to increase the average number of roots/mini-cutting.

Regarding average length of the three largest roots of mini-cuttings, there was again significant interaction according to regression analysis performed for this variable (Figure 4B). Best result was achieved with the maximum estimated point with concentration of $4.723 \mathrm{mg} \mathrm{L}^{-1}$ of IBA, combined with carbonized rice hull, obtaining the average length of the three largest roots of $4.88 \mathrm{~cm}$. 

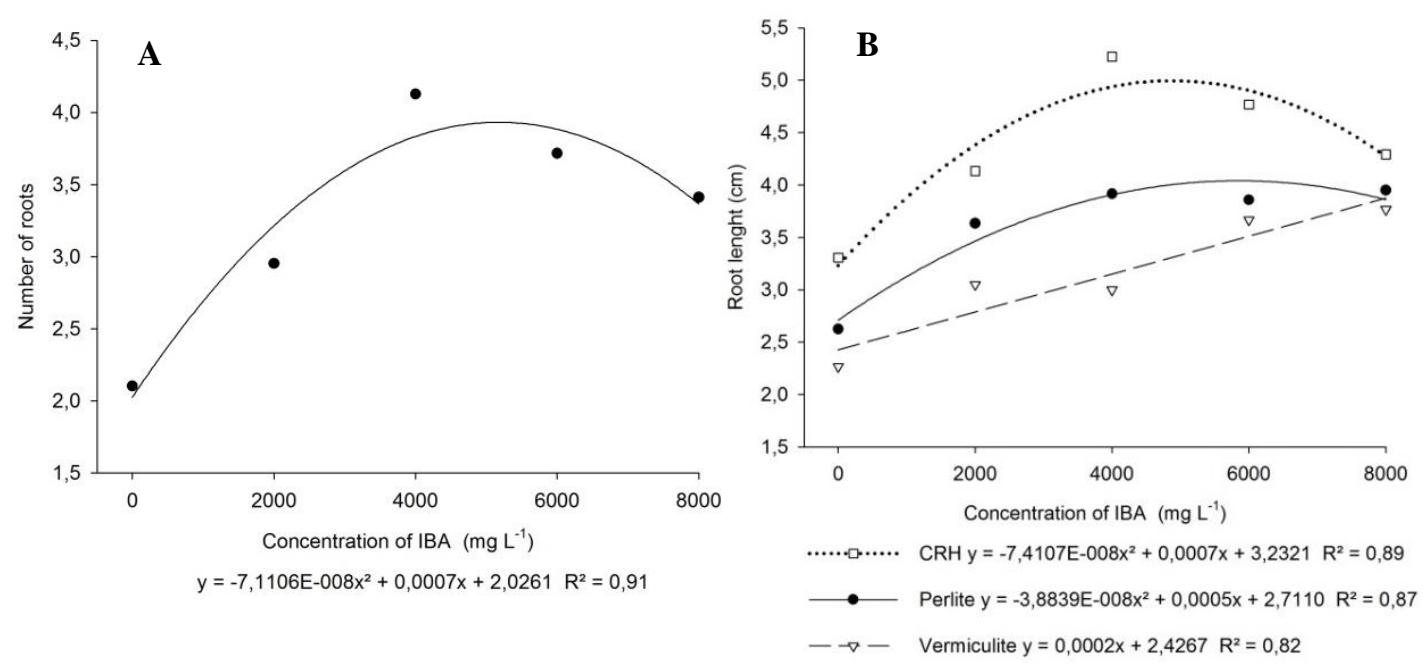

Figure 4. Average number of roots (A) and average length of the three largest roots (B) of mini-cuttings of Carya illinoinensis submitted to concentrations of IBA and substrates. CRH: Carbinized Rice Hull.

Figure 4. Average number of roots (A) and average length of the three largest roots (B) of Carya illinoinensis mini-cuttings submitted to concentration of IBA and substrates. CAC: Carbonized Rice Husk.

The average variables of fresh and dry mass of roots of the mini-cuttings were directly influenced by the concentrations of IBA and substrates, in which superior results were obtained with maximum estimated points with IBA concentrations of 4,357 $\mathrm{L}^{-1} \mathrm{mg}$ and obtaining $998.73 \mathrm{mg}$ for fresh root mass (Figure $5 \mathrm{~A}$ ) and 4,644 mg $\mathrm{L}^{-1}$ and obtaining $465.89 \mathrm{mg}$ dry root mass (Figure 5B), combined with the carbonized rice hull substrate. The superior results for these variables were obtained mainly due to the maximum estimated point ranges being close to the concentration of $4,000 \mathrm{mg} \mathrm{L}^{-1}$ of IBA for evaluated variables that directly influence the weight of the fresh and dry mass of the mini-cuttings roots, such as the length of roots and number of roots of Carya illinoinensis mini-cuttings, which obtained superior results close to this range of $4,000 \mathrm{mg} \mathrm{L}^{-1}$ of IBA together with carbonized rice hull substrate.
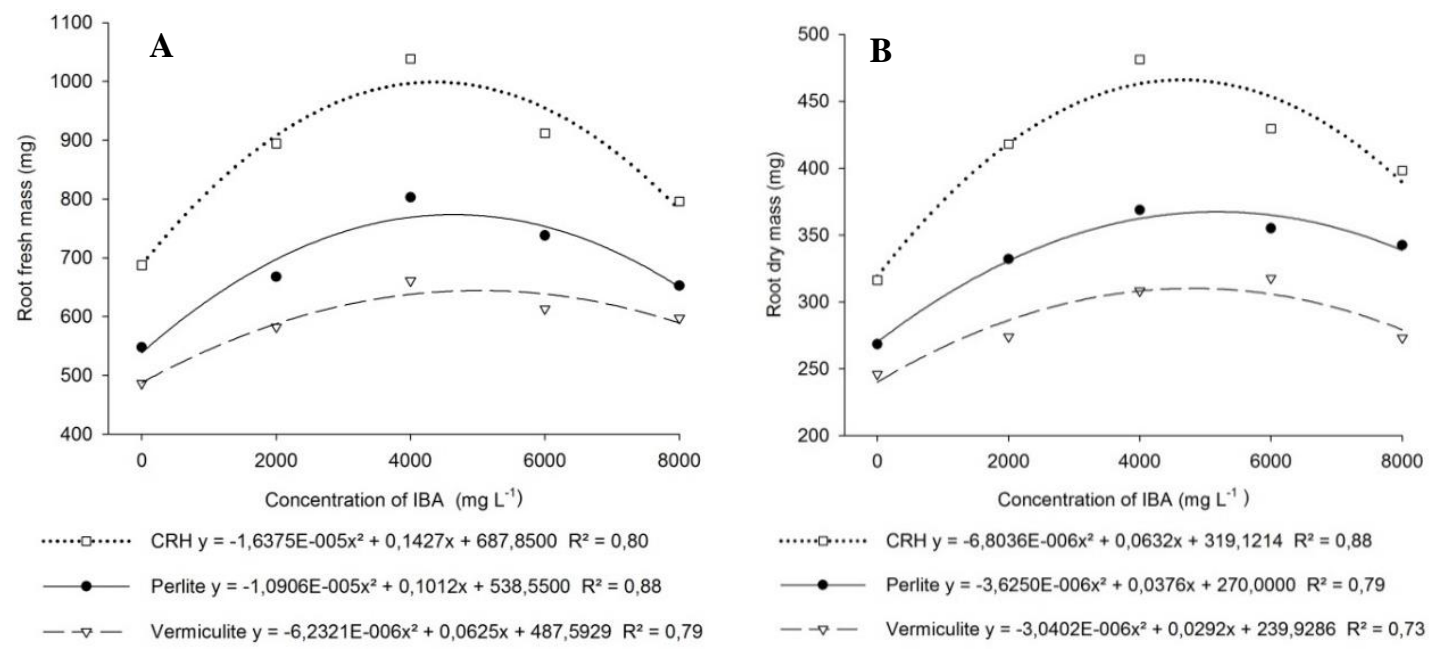

Figure 5. Average fresh weight (A) and dry weight (B) of mini-cuttings of Carya illinoinensis submitted to IBA and substrate concentrations. (CRH: Carbonized Rice Hull).

Figura 5. Média de massa fresca (A) e massa seca (B) de miniestacas de Carya illinoinensis submetidas a concentração de AIB e substratos. (CAC: Casca de Arroz Carbonizada).

In terms of substrates analysis used in this study, it is observed that carbonized rice hull had a greater aeration space (AE) and less water retention capacity (WRC) in relation to other substrates used in the experiment (Table 1), respectively with $68.67 \%$ (AE) and $16.31 \%$ (WRC 10) at the time of the experiment installation and $70.68 \%$ (AE) and $20.78 \%$ (WRC 10) after 60 days of the experiment installation, which probably favored the development of the roots and, consequently, the rooting of pecan mini-cuttings, considering the irrigation system used. 
Table 1. Average values of $\mathrm{pH}$, electrical conductivity (EC), aeration space (AE) and water retention capacity (WRC) under suction of $10 \mathrm{~cm}$ of water column (WRC 10) of three substrates used in Carya illinoinensis mini-cuttings.

Tabela 1. Valores médios de pH, condutividade elétrica (CE), espaço de aeração (EA) e capacidade de retenção de água sob sucção de $10 \mathrm{~cm}$ de coluna de água (CRA 10) de três substratos utilizados na miniestaquia de Carya illinoinensis.

\begin{tabular}{lcccc}
\hline Substrate & pH $(\mathbf{H 2 O})$ & CE $(\mathbf{m S} . \mathbf{~ c m}-\mathbf{1})$ & AE $(\%)$ & WRC 10 (\%) \\
\hline CRH1 ${ }^{*}$ & 7.28 & 0.070 & 68.67 & 16.31 \\
Vermiculite & 6.22 & 0.010 & 22.20 & 50.71 \\
Perlite & 6.50 & 0.010 & 24.61 & 32.05 \\
CRH 60D2 & 6.41 & 0.020 & 70.68 & 20.78 \\
Vermiculite 60D & 6.47 & 0.023 & 30.77 & 61.15 \\
Perlite 60D & 6.56 & 0.016 & 33.52 & 48.12 \\
\hline CV $(\%)$ & 1.12 & 13.33 & 4.23 & 5.10
\end{tabular}

$* \overline{1 \mathrm{CRH}}=$ Carbonized rice hul; $260 \mathrm{D}=60$ days of substrate permanence in an agricultural greenhouse with intermittent misting; $\mathrm{CV}$ : Coefficient of variation

\section{DISCUSSION}

The application of IBA favored the formation of callus and rooting in Carya illinoinensis, characterizing the effect of the application of exogenous auxin in the process of propagation by mini-cuttings of the species. According to Hartmann et al. (2011), callus formation, which consists of a mass of parenchyma cells, can be an independent process, however for species that have difficult rooting, root formation can occur in the place where the callus originated. The formation of a radical system in mini-cuttings can occur indirectly through the formation of callus, which consists of an undifferentiated tissue and in a direct way, in which there is no callus formation, with the formation of early adventitious roots from cells associated with the vascular system (MOREIRA et al., 2000). However, in some species, the formation of callus is not a sign of the formation of roots, but consists in the healing of a cut or barrier to its development (FACHINELLO et al. (2005).

Auxins act as root formation signals, due to their action synergistically or antagonistically with other hormones to trigger events that lead to the initiation of rooting, in which exogenous application has a fundamental role in the rooting of mini-cuttings of different species (PACURAR et al., 2014). Root formation in Carya illinoinensis mini-cuttings was only observed in mini-cuttings with callus formation, in which a positive correlation of 0.95 was obtained, characterizing as a strong correlation between callus formation and rooting variables, highlighting a characteristic of the rooting of species mini-cuttings. Callus formation and rooting showed similar concentrations of IBA at their maximum estimated points, however, from concentrations above this point, there was a decrease in the percentage of mini-cuttings with callus formation and rooting. According to Meneguzzi et al. (2015), the increase in the concentration of exogenous auxin, applied in mini-cuttings, causes an adventitious rooting stimulating effect up to a certain maximum value, after which any increase in the content of this plant regulator has an inhibitory effect. Thus, IBA concentrations higher than the maximum estimated points of the regression curve caused an inhibitory effect on Carya illinoinensis mini-cuttings, reducing the formation of callus and rooting, in addition to causing necrosis at the basal end of mini-cuttings of the species.

Similar results were obtained with mini-cuttings from eight-month-old plants of Juglans nigra L., a species from the same botanical family as the pecan, in which, after the maximum rooting point with the use of IBA, there was a decrease in the percentage of rooted mini-cuttings of the species (STEVENS; PIJUT, 2017). According to Hartmann et al. (2011), the immersion time of the application of synthetic rooting hormones can also influence the results obtained, with long immersions lasting hours or rapid immersions that last only a few seconds, as was the form of application in this study, and a similar effect was observed at very high concentrations (Figure $3 \mathrm{~A})$.

The highest number of roots for the mini-cuttings was obtained with the maximum estimated point with the concentration of $4,922 \mathrm{mg} \mathrm{L}^{-1}$ of IBA. According to Xavier et al. (2013), adequate IBA concentrations vary according to the species and favor the formation of adventitious roots, mainly due to their lower chemical mobility and greater stability in the cutting, however supra-optimum concentrations can inhibit the formation of roots. Pizzato et al. (2011), when testing the concentrations of $0,250,500,1,000$ and 2,000 mg L-1 of IBA in hibiscus cuttings (Hibiscus rosa-sinensis L.), better results were obtained with the increase of these concentrations, being the optimal concentration fixed at $1,600 \mathrm{mg} \mathrm{L}^{-1}$. 
The average length of roots was also positively influenced by IBA use with maximum estimated point with the concentration of $4,723 \mathrm{mg} \mathrm{L}^{-1}$ of IBA, combined with carbonized rice hull. According to Hartmann et al. (2011), auxins used in propagation by cuttings can promote the development of a better quality root system in terms of vigor, uniformity and volume of roots in rooted cuttings. The use of exogenous auxins has the capacity to increase the cell division process, causing the formation and elongation of roots (ENDERS \& STRADER, 2015). Pizzato et al. (2011) it is also reported that, due to the fact that IBA induces rhizogenesis more quickly, this regulator favors the obtaining of the longest cuttings root lengths. The effect of auxins is largely related to the increase in cell division, as well as cell elongation. Thus, in pecan mini-cuttings there was a positive effect on root length (GUAN et al., 2015). Bettoni et al. (2014) correlate the use of IBA for the rooting of vine cuttings, with other factors such as cuttings collection time and genotype and it was observed that the application of $1000 \mathrm{mg} \mathrm{L}^{-}$ ${ }^{1}$ of IBA, in herbaceous cuttings of the VR043-43 vine rootstock improves the quality of rooted seedlings, due to the formation of greater number, length and fresh mass of roots.

For fresh and dry root mass, the results were also superior in treatments with $4,000 \mathrm{mg} \mathrm{L}^{-1}$ of IBA combined with the carbonized rice hull substrate. According to Hartmann et al. (2011), the response to the rooting of some species is related to the chemical and physical composition of some substrates, mainly in relation to the diffusion of gases and aeration According to the same author, some substrates can maintain a high amount of water and obstruct the passage of oxygen, directly affecting the development and growth of the initial roots due to the formation of a blade around the cuttings, thus impairing the rooting and development of the roots. Sarmiento et al. (2015) found that the rooting (80.3\%) of Ficus cestrifolia Schott ex Spreng cuttings showed an increasing response with the increase of IBA concentrations in which, those maintained without nebulization, obtained greater responses in the concentration of $4,000 \mathrm{mg} \mathrm{L}^{-1}$.

According to Xavier et al. (2013), the substrates used in the propagation by cuttings must present good aeration, since oxygen is indispensable for the formation and emergence of roots, with variation of the substrates in relation to the environment and species. This good aeration also prevents excessive moisture retention, which could cause damage to the development of roots and a favorable environment for root pathogens.

According to Kämpf et al. (2006), the intermittent misting system directly influences the choice of the substrate, requiring high aeration space and rapid drainage, due to the high frequency that water is offered to the propagating material. The nebulization system used in the experiment had a short activation interval of 5 minutes and an irrigation period of 15 seconds during the day ( $7 \mathrm{am}$ to $7 \mathrm{pm}$ ) and activation every 15 minutes and an irrigation period of 15 seconds at night ( $7 \mathrm{pm}$ to $7 \mathrm{am}$ ). Thus, the carbonized rice hull showed the best results, under the experimental conditions tested, as it contained the largest aeration space and the lowest water retention capacity on the cuttings, thus providing better conditions for the rooting of juvenile cuttings of Carya illinoinensis.

Souza et al. (2006), point out that the use of pure carbonized rice hulls should be conducted in systems with high intensification of irrigation frequency. The vermiculite and perlite substrates showed lower AE and higher WRC 10 in relation to the carbonized rice hull, directly influencing the analyzed variables related to rooting in the experimental conditions tested (Table 1). Kratz et al. (2015) tested renewable substrates for the production of yerba mate seedlings (Ilex paraguariensis A. St.-Hil.), and found that those that contained balanced proportions of coconut fiber and carbonized rice hulls provided better radical characteristics.

When conducting propagation by mini-cuttings, the $\mathrm{pH}$ and electrical conductivity variables have a low influence on the initial rooting phase, due to being mainly related to the absorption of nutrients, development of the root system and aerial part of plants after rooting. All the substrates used had acidity, except for the carbonized rice hull, with a more alkaline $\mathrm{pH}$ at the time of the installation of the experiment (7.28). In terms of electrical conductivity, all substrates had low values for this variable.

In the experimental conditions of this study and with the use of Carya illinoinensis mini-cuttings, there is the possibility of propagating the species in an asexual manner through the use of the mini-cutting technique. The use of treatments with carbonized rice hull substrate combined with that of IBA auxins, with maximum estimated points close to the concentration of $4,000 \mathrm{mg} \mathrm{L}^{-1}$, provided superior results for variables related to rooting in a quantitative way, highlighting the possibility of rooting of mini-cuttings of Carya illinoinensis.

Besides the quantitative points obtained with rooting, there was an improvement in qualitative aspects in the formation of the radical system, which play a fundamental role in improving the development of seedlings propagated by the mini-cutting method, such as greater length and dry mass of roots of the mini-cuttings, in addition to the number of roots per mini-cutting.

\section{CONCLUSION}

The concentration of 4,000 $\mathrm{mg} \mathrm{L}^{-1}$ IBA is recommended combined with carbonized rice hull substrate for vegetative propagation by mini- cuttings of juvenile plants of Carya illinoinensis in an agricultural greenhouse with intermittent misting. 


\section{ACKNOWLEDGEMENTS}

To Conselho Nacional de Desenvolvimento Científico e Tecnológico - CNPq (National Council for Scientific and Technological Development) for granting the scholarship to the first author and to Pró-Reitoria de Pesquisa - PROPESQ (Dean's Office for Research Studies) - UFRGS (Federal University of Rio Grande do Sul) for granting the scholarship to the third author.

\section{REFERENCES}

BETTONI, J.C.; Gardin, J.P.; Feldberg, N.P.;Schumacher, R.; Petri, J.L.; Souza, J.A. Indução do enraizamento em estacas lenhosas do porta enxerto de videira vr043-43 submetidas a lesões e aplicação de auxinas. Evidência, Joaçaba, v. 14 n. 2, p. 129-138, jul./dez. 2014.

BRASIL. Ministério da Agricultura, Pecuária e Abastecimento. Regras para análise de sementes. Brasília: Coordenação Geral de Apoio Laboratorial. Secretaria de Defesa Agropecuária, Brasília, 2009. 399 p.

ENDERS, T.A.; STRADER, L.C. Auxin activity: past, present, and future. American Journal of Botany, Baltimore, v.102, p.180-196, fev. 2015.

FACHINELlO, J. C.; HOFFMANN, A.; NACHTIGAL, J. C. Propagação de plantas frutíferas. Brasília: Embrapa informação tecnológica, 2005. 221 p.

FACHINELLO, J.C.; PASA, M.S.; SCHMTIZ, J.D.; BETEMPS, D. L. Situação e perspectivas da fruticultura de clima temperado no Brasil. Revista Brasileira de Fruticultura, Cruz das Almas, v.especial, p.109-120, out. 2011.

HAMANN, J.J. et al. Cultivares de nogueira-pecã no Brasil. Pelotas: Embrapa Clima Temperado, 2018. 43p.

HARTMANN, H.T. et al. Plant propagation: principles and practices. 8th. ed. Upper Saddle River: PrenticeHall, 2011.915 p.

GUAN, L.; MURPHY, A.; PEER, W.; GAN, L.; LI, Y.; CHENG, M. Physiological and molecular regulation of adventitious root formation. Critical Reviews in Plant Science, Phyladelphia, v.34, p. 506-521, nov. 2015.

INTERNATIONAL NUT AND DRIED FRUIT COUNCIL FOUNDATION. Nuts \& dried fruits: statistical yearbook 2017/2018. Disponível em: <https://www.nutfruit.org/ >. Acesso em: 20 mar. 2020

KRATZ, D.; PIRES, P.P.; STUEPP, C.A.; WENDLING, I. Produção de mudas de erva-mate por miniestaquia em substratos renováveis. Floresta, Curitiba, v. 45, n. 3, p. 609 - 616, 2015.

KÄMPF, A.N. Produção comercial de plantas ornamentais. 2. ed. Guaíba: Agrolivros, 2005. 254 p.

KÄMPF, A.N.; TAKANE, R.J.; SIQUEIRA, P.T.V. Floricultura: técnicas de preparo de substratos. Brasília: LK Editora e Comunicação, 2006. 132p.

MENEGUZZI, A.; NAVROSKI, M.C.; LOVATEL, F.T.M; PEREIRA, M.O.; TONETT, E.L. Ácido indolacético influencia no enraizamento de estacas de Pittosporum tobira. Revista de Ciências Agroveterinárias, Lages, v.14, n.1, p.24-28, 2015.

MOREIRA, M.F.; GLORIA, B.A.; ZAIDAN, L.B.P. Anatomical aspects of IBA-treated microcuttings of Gomphrena macrocephala St.-Hil. Brazilian Archives of Biology and Technology, Curitiba, v.43, n.2, p. 221227, 2000.

PACURAR, D. L.; PERRONE, I.; BELLINI, C. Auxin is a central player in the hormone cross-talks that control adventitious rooting. Physiologia Plantarum, Sweden, v.15, p. 83-96, 2014.

PEREIRA, L.D.; COSTA, M.L.; PINTO, J.F.N.; ASSUNÇÃO, H.F.; REIS, E.F.; SILVA, D.F.P. Propagação de gabirobeiras via estaquia associada ao ácido indolbutírico. Revista Brasileira de Agropecuária Sustentável, Viçosa, v.7, n.1, p.19-25, 2017.

PIZZATO, M.; WAGNER JÚNIOR; A.; LUCKMANN, D.; PIROLA, K.; CASSOL, D.A. MAZARO, S.M. Influência do uso de AIB, época de coleta e tamanho de estaca na propagação vegetativa de hibisco por estaquia. Revista Ceres, Viçosa, v. 58, n.4, p. 487-492, 2011.

SANDERLIN, R.S. Susceptibility of some common pecan rootstocks to Infection by Xylella fastidiosa. Hortscience, Alexandria, v.50, n.8, p. 1183-1186. 2015. 
SARMIENTO, A.I.; SOUZA, P.V.D.; FIOR, C.S. Estaquia de Ficus cestrifolia Schott ex Spreng.: concentrações de ácido indol-3-butírico e ambientes de enraizamento. Iheringia, Porto Alegre, v. 70, n. 1, p. 167-172, 2015.

SOUZA, P.V.D.; CARNIEL, E.; FOCHESATO. Composição do substrato no enraizamento de estacas de maracujazeiro azedo. Revista Brasileira de Fruticultura, Jaboticabal, v.28, n.2, p.276-279, 2006.

STEVENS, M. E.; PIJUT, P. M. Origin of adventitious roots in black walnut (Juglans nigra) softwood cuttings rooted under optimized conditions in a fog chamber. New Forests, Dordrecht, v. 48, n. 5, p. 685-697, 2017.

TRONCO, K.M.; BISOGNIN, D.A.; FLEIG, F.D.; HORBACH, M.A. Enraizamento ex vitro e aclimatização de microestacas de Ilex paraguariensis A. St Hil. Cerne, Lavras, v. 21, n. 3, p. 371-378, 2015.

XAVIER, A.; WENDLING, I.; SILVA, R. L. Silvicultura clonal: princípios e técnicas. 2. ed. Viçosa: Universidade Federal de Viçosa, 2013. 279 p.

YAMAMOTO, L. Y. et al. Substrates on rooting of blackberry Xavante herbaceous cuttings. Ciência Rural, Santa Maria, v. 43, n. 1, p. 15-20, 2013.

ZEM, L.M.; ZUFFELLATO-RIBAS, K.C.; RADOMSKI, M.I.; KOEHLER, H.S. Rooting of semi-hardwood stem cuttings from current year shoots of Drymis brasiliensis. Ciência Rural, Santa Maria, v.46, p.2129-2134, 2016. 